\title{
OVERVIEW OF THE GEOLOGY AND EMPLACEMENT OF THE JWANENG DK2 KIMBERLITE, SOUTHERN BOTSWANA
}

\author{
Kimberley Webb ${ }^{1}$, Johann Stiefenhofer ${ }^{2}$ and Matthew Field ${ }^{3}$ \\ ${ }^{I}$ De Beers Canada Kimberlite Petrology Unit, Canada; ${ }^{2}$ De Beers Central Headquarters, South Africa; ${ }^{3}$ De Beers Central \\ Mines, South Africa
}

\section{INTRODUCTION}

The Permian ( $245 \mathrm{Ma})$ Jwaneng kimberlite is situated in southern Botswana, in the northwestern part of the Kaapvaal craton (Fig. 1). This study represents the first published overview of the geology of the Jwaneng kimberlite since its discovery in 1973. The kimberlite comprises three steep-sided pipes that coalesce approximately $100 \mathrm{~m}$ below the present day surface to form a 54ha body. These pipes have been labelled the South, Centre and North Lobes (Fig. 2). Although the shapes of these pipes are comparable to other southern African pipes, they are filled to considerable depth $(600 \mathrm{~m}+)$ with crater facies volcaniclastic kimberlite. No tuffisitic kimberlite breccia (after the classification of Clement and Skinner, 1985), common in steep-sided southern African kimberlites, has to date been identified in these pipes. Thus, the Jwaneng kimberlite appears to represent an exception to the standard kimberlite geology of southern African kimberlites.

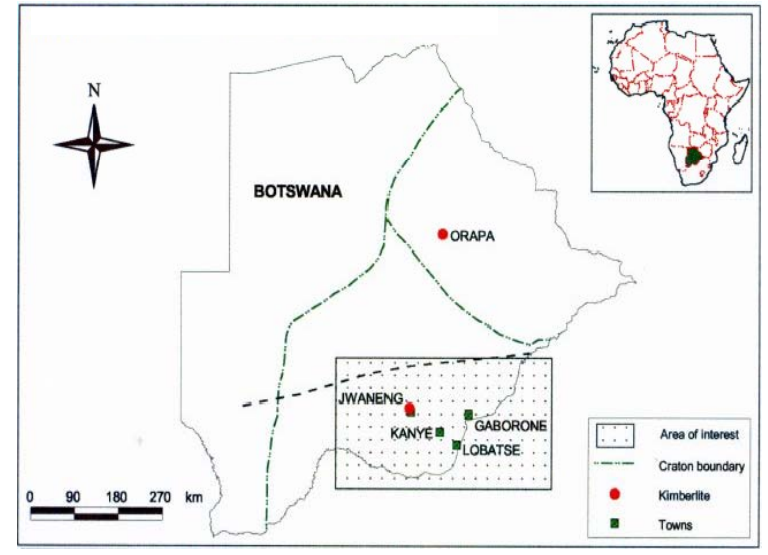

Figure 1: Locality map showing the position of Jwaneng Mine in southern Botswana (modified from Machin, 2001).

The Jwaneng kimberlites were emplaced into a thick sequence of Proterozoic shales, dolomites and sandstones and a thin veneer of consolidated to poorly consolidated mudstones and siltstones of the now-eroded Karoo Supergroup. Erosion since emplacement is estimated to be in the order of 250 to $300 \mathrm{~m}$ (Machin, 2001). The kimberlite volcanism occurred under subaerial conditions during deposition of the Karoo sediments.

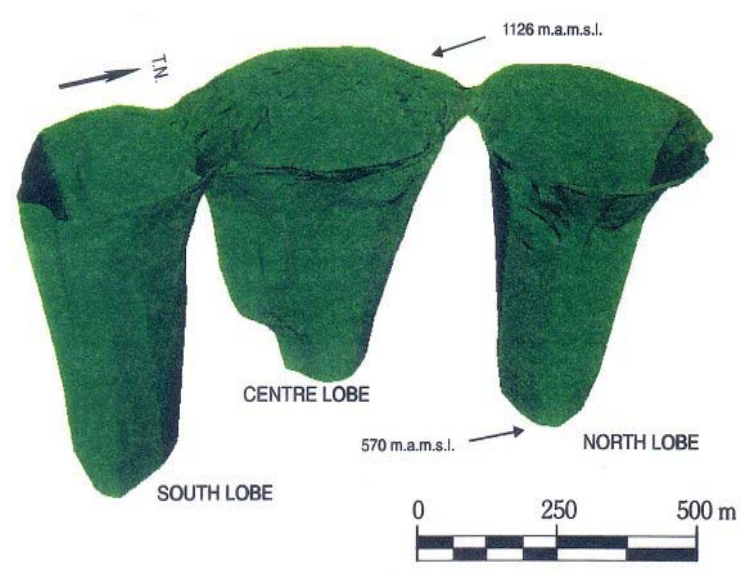

Figure 2: Oblique view of the three pipes (lobes) of the Jwaneng kimberlite, looking west-northwest.

\section{GENERAL KIMBERLITE GEOLOGY}

The Jwaneng pipes are dominated by two contrasting textural types of kimberlite, which have been interpreted as (a) resedimented volcaniclastic kimberlite and (b) dark pyroclastic kimberlite.

\section{RESEDIMENTED VOLCANICLASTIC KIMBERLITE (RVK)}

Two principal types of RVK have been identified at Jwaneng, viz. quartz-free resedimented volcaniclastic kimberlite (RVK) and quartz-rich RVK (QRVK) (Fig. 3). The quartz-free RVK is the volumetrically most abundant geological unit in all three lobes, whereas the quartz-rich QRVK is best developed in the South Lobe, less so in the Centre Lobe, and virtually absent in the North Lobe. The QRVK is typically restricted to a narrow discontinuous marginal zone ( $0-15 \mathrm{~m}$ thick) immediately adjacent to the pipe contact.

Both rock types are dominated by massive and chaotic material, with subordinate laterally discontinuous, normal and reverse graded planar bedded zones displaying oversteepened dips, as well as common rotated blocks of earlier, partially or 
totally consolidated volcaniclastic material. Slickenside-bound planes and/or broken/rubble zones frequently define the contacts between the blocks and the host. The RVK and QRVK are further characterised by the common presence, in localised areas, of quartz-bearing, massive or finely laminated ash-sized/muddy kimberlite that occurs as irregular inclusions ranging up to a few metres in size. Slump structures and/or micro-faulting may be present in this material. The dominant country rock xenolith in both the RVK and QRVK is Proterozoic shale, with the various other xenolith types displaying an overall uniform distribution. Xenolithic clasts rarely exceed a meter in size, with the majority being less than $150 \mathrm{~mm}$. Subround quartzite clasts appear to occur only in the QRVK, which possibly relates to the presence of quartz in this unit. Localised shale-rich avalanche/collapse breccias have been identified near the pipe contacts in the South and Centre Lobes. These are dominated by angular Proterozoic shale clasts that range in size up to a meter and occur in a fine grained matrix of closely-packed juvenile and xenolithic constituents. All three lobes contain a number of large (up to $30 \mathrm{~m}$ ) wall-rock inclusions that consist predominantly of Karoo mudstone or siltstone and occur exclusively around the periphery of the pipes, close to the wall-rock contact. No large blocks of Proterozoic shale have yet been found within any of the lobes.

The quartz-free RVK zones within the North Lobe can be subdivided into distinct mappable units, some containing unique geological features. The uppermost RVK, for example, is characterised by reddishoxidised bomb-sized magmatic fragments. Discontinuous, rotated blocks of volcaniclastic material are especially common within the quartzfree RVK of the North Lobe.

Texturally the RVK and QRVK are magmaclastic (terminology after Field and Scott Smith, 1998), dominated by lapilli-sized (4-32mm) components, and are typically clast supported and poorly sorted, although localised zones displaying increased degrees of sorting and/or matrix support do occur. The RVK is rich in juvenile components $(50-70 \%$; discrete mantle-derived and phenocrystal olivine, juvenile lapilli, other mantle-derived xenocrysts), with a low to moderate country rock xenolith content (10-25\%) and little or no quartz or feldspar. The QRVK, in contrast, is characterised by a comparatively low juvenile content (15-45\%) and a high xenolith content (10-20\%), including contorted Karoo mudstone clasts and abundant angular quartz and feldspar grains $(20-40 \%)$, presumably derived from disaggregation of the now-eroded sedimentary cover rocks (Machin, 2001). The juvenile and lithic components in both rock types are set in a very fine grained inter-clast matrix composed of clay minerals, very finely comminuted juvenile and lithic fragments, disaggregated Karoo mudstone and lesser serpentine.

The juvenile lapilli population of each unit includes relatively well-crystallised and texturally wellpreserved, mainly round and subround types and lesser irregular and subangular varieties. Two mineralogical varieties of kimberlite are present: monticellite kimberlite and monticellite-calcite kimberlite. Very rare examples of accretionary and armoured lapilli occur in both the RVK and QRVK, being best-preserved in the ash-sized/muddy kimberlite. Volcaniclastic kimberlite autoliths are present in both rock types and are generally texturally and compositionally similar to the host rock.

\section{DARK PYROCLASTIC KIMBERLITE}

Dark, competent, well-bedded and graded juvenilerich material (Fig. 4) has been exposed in the central part of the North Lobe. The pyroclastic kimberlite $(\mathrm{PK})$ is comprised of multiple upward-fining sequences, which range in thickness from several meters to tens of meters. The sequences can be loosely subdivided into three gradational units, viz. A, B and C (top to bottom), based on the abundance of lithic material and saponite clays in the matrix. The very low lithic abundance, low modal saponite clays and very high proportion of discrete olivine and juvenile magmatic constituents of the uppermost unit (A) contrasts with the lithic- and clay-rich basal unit (C). The units are repetitive throughout the volcanic pile, but all three are not present everywhere, with units $\mathrm{A}$ and $\mathrm{B}$ being most common. Texturally the PK is magmaclastic, dominated by lapilli-sized components and overall clast supported and poorly to moderately sorted. Both mineralogical varieties of kimberlite present in the RVK are represented in the juvenile lapilli of the PK. The lithic component is dominated by Proterozoic shales. Autolithic RVK fragments are common, whereas no convincing accretionary lapilli have been identified.

Compared to the RVK, the $\mathrm{PK}$ is characterised overall by a much lower saponite clay and higher serpentine content. This is reflected in the 'clean', serpentine-rich nature of the inter-clast matrix, which contrasts with the fines-rich, muddy RVK matrix (magmatic versus non-magmatic/exotic inter-clast matrix, after Field and Scott Smith, 1998). 


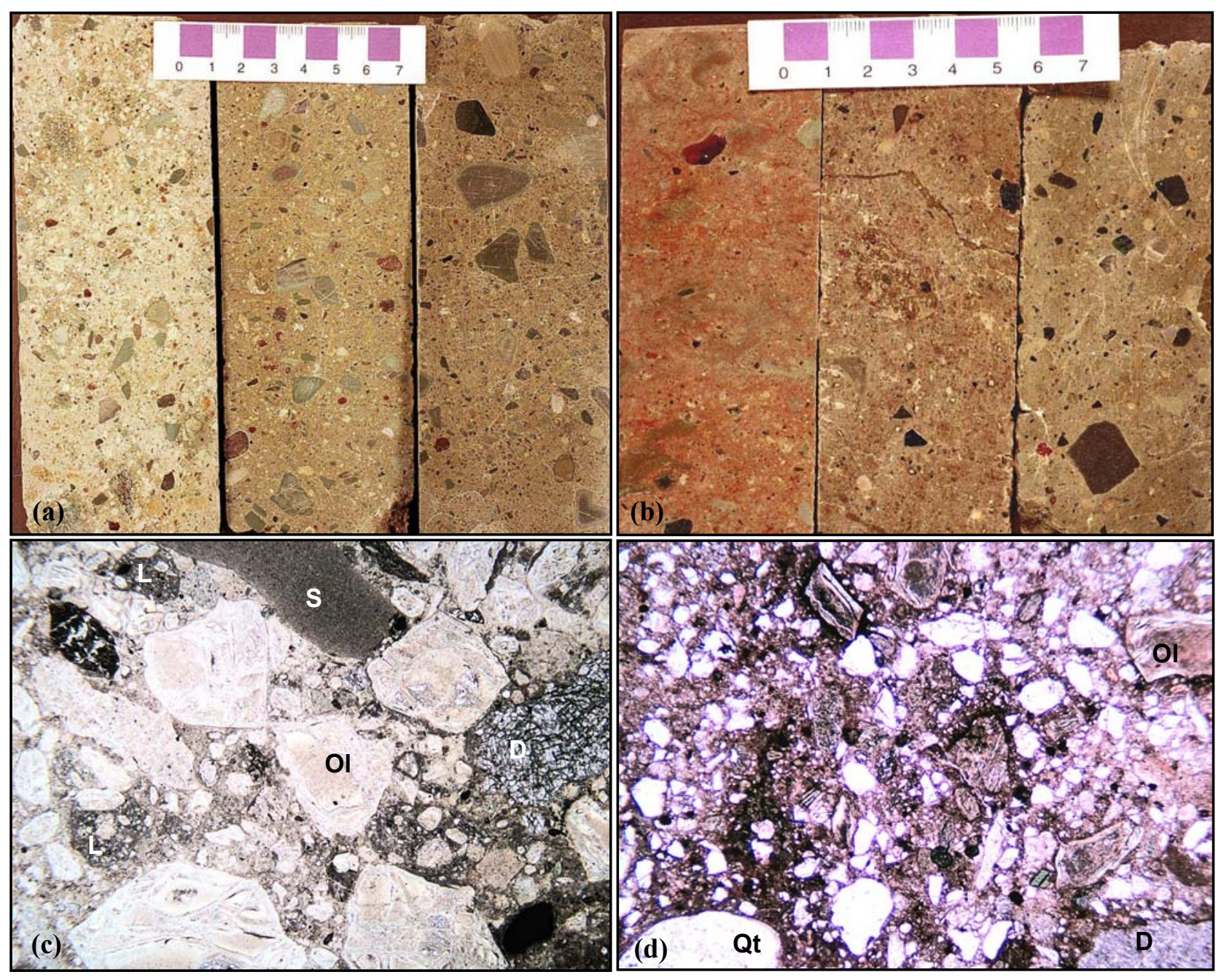

Figure 3 (a) - (d): Drillcore samples of the (a) massive RVK and (b) massive QRVK, South Lobe (from Machin, 2001). Note the fragmental, poorly sorted texture, abundant Proterozoic shale fragments and the contorted mudstone clasts in the QRVK. Scale bar in centimeters. Photomicrographs of the (c) RVK and (d) QRVK, South Lobe (from Machin, 2001), showing the typical clast supported, poorly sorted texture. The RVK consists of altered discrete olivine (Ol) macrocryst and phenocryst grains, juvenile lapilli (L), shale (S) and dolomite (D) xenoliths in a clay-dominated matrix. PPL, FOV=5.2mm. The QRVK comprises abundant subangular to angular, strained quartz and feldspar grains, altered olivine (Ol), dolomite (D) and quartzite (Qt) xenoliths in a clay-rich matrix. PPL, FOV=2.75mm.

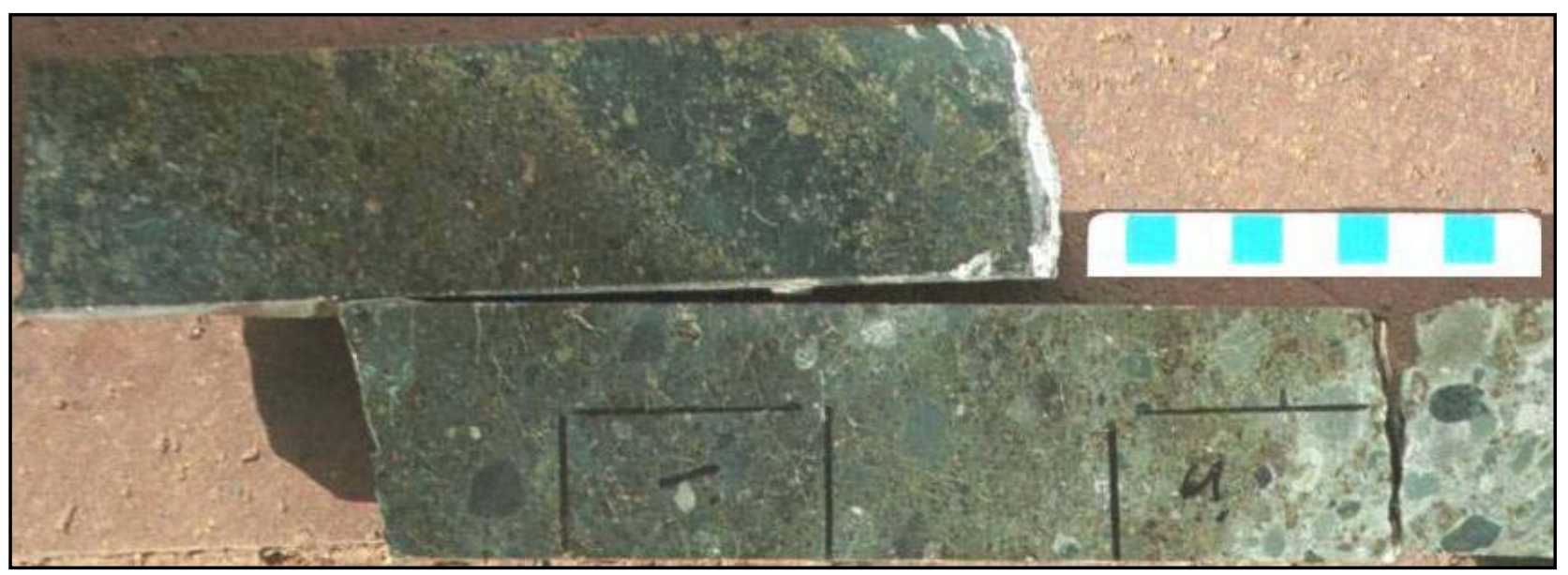

Figure 4: Example of a normally graded sequence in the pyroclastic kimberlite in the North Lobe, showing a basal lithic-rich unit (bottom right) grading upwards to a dark juvenile-rich, lithic-poor unit (top left). Scale bar in centimeters. 
The PK is also much harder and higher in density than the RVK and is further characterised by a higher diamond grade. The PK is easily misinterpreted as hypabyssal (magmatic) in isolated hand specimens. No such PK material has to date been exposed in the Centre Lobe. Rocks of similar appearance, but much less extensive, have only recently been discovered in the central part of the South Lobe and are still subject to further investigation.

\section{DISCUSSION}

The presence within the RVK and QRVK of: (i) nonmagmatic fines/clay-dominated inter-clast matrices, (ii) discontinuous normal and reverse graded planar bedding, slump structures and micro-faulting, (iii) localised shale-rich avalanche deposits, (iv) common autolithic fragments and rotated blocks of earlier, partly or totally consolidated volcaniclastic material, and (v) common large blocks and small contorted fragments of the poorly consolidated sediments that formed the pre-eruptive land surface, all support the classification of these rocks as resedimented volcaniclastic kimberlite. Resedimented volcaniclastic kimberlite is used in this study to describe volcaniclastic kimberlite for which depositional mechanisms can be ascribed to short-lived mass flow redeposition processes. Gravitational resedimentation is distinguished from tractional reworking, which may involve significant textural modification (abrasion, rounding of clasts).

The contrasting characteristics of the PK in the North Lobe, particularly the presence of serpentine-rich (magmatic) inter-clast matrices and the notable absence of the RVK features listed above, support a primary pyroclastic origin for these rocks. The nature of the repeated similar normally graded sequences up to tens of meters in thickness suggests pyroclastic airfall as the dominant depositional process.

The well-crystallised and often primary calcitebearing juvenile lapilli in the QRVK, RVK and PK contrast markedly with the thin-selvaged, quenched so-called pelletal lapilli found in the pipe infills of most other southern African kimberlites (Field and Scott Smith, 1999). Furthermore, microlitic diopside, which is common in the latter, appears to be absent in these rocks. These characteristics, together with the inhomogeneity of the Jwaneng pipe infills, preclude a tuffisitic kimberlite (Clement and Skinner, op cit) interpretation. Since the emplacement model developed for most other southern African kimberlite pipes (Clement and Reid, 1989) does not appear to apply to the Jwaneng kimberlite, different processes are invoked to explain its formation.

\section{EMPLACEMENT PROCESSES}

Contact relationships exposed during mining suggest that formation of the South Lobe preceded that of the Centre Lobe. Due to severe calcretisation, the relationship between the Centre and North Lobes is uncertain, but it is speculated that the North Lobe represents the final vent-forming episode.

The dominant infill of all three of the pipes at Jwaneng is resedimented volcaniclastic kimberlite (RVK). The distinct petrographic differences and spatial distribution of the QRVK and RVK in the Centre and South Lobes suggest two possible interpretations for their formation. The first is that they are the products of at least two separate eruptions, with the QRVK representing resedimented ejecta from the first event, and the RVK that of the second (Machin, 2001). The second eruption would have cored out the initial pipe infill, ejecting most of the material out of the crater and leaving only a discontinuous remnant along the pipe margins (QRVK). Based on the contrasting juvenile and xenolithic contents of the RVK and QRVK, the first eruption (QRVK) was the dominant vent-clearing episode. The absence of quartz/feldspar within the RVK suggests that the second eruption event must have resulted in wide extra-crater dispersal of the QRVK pipe infill.

Alternatively, the QRVK may represent parts of the partly- or unconsolidated base of the tephra ring that slumped back into the crater whilst one overall eruption was in progress. In this case, the QRVK, representing the initial phases of the eruption, must have subsided into an open or constantly widening crater in order to be preserved in direct contact with the pipe margins. Either model may explain the very localised distribution of the QRVK and the variable nature of the contacts between the RVK and QRVK, $v i z$. sharp to gradational.

In either scenario described above, the surface environment must have been highly unstable during the eruption(s). The unconsolidated nature of the extra-crater debris and undermining of the tephra ring by collapse of parts of the underlying pipe walls would have resulted either in resedimentation of the ejecta soon after pipe excavation, or a constant flow of material back into the open vent during eruption. Large-volume debris flows produced a chaotic, unstructured deposit and localised grain flow on debris cones formed laterally discontinuous, reverse graded planar bedding. 
The mechanism(s) responsible for the explosive volcanism at Jwaneng remains speculative at this stage. The presence of rare armoured and accretionary lapilli, particularly within the South Lobe (Machin, 2001), provides unequivocal evidence for the presence of water during the eruption(s), although the nature and extent of phreatomagmatic activity is difficult to determine. Evidence to suggest the presence of possible base surge deposits, occurring as thinly bedded blocks that probably represent downrafted portions of a crater rim succession, was found in the RVK deposits of the North Lobe, and possibly within the Centre Lobe.

In the case of the South and Centre Lobes, which to date appear to be infilled entirely by RVK and QRVK, the eruption style and associated resedimentation processes must have remained reasonably consistent. This is in contrast to the North Lobe, where formation of the RVK was followed by a final phase of eruption characterised by primary airfall processes that yielded dark pyroclastic kimberlite deposits. Minor air-fall activity may also have occurred in the South Lobe.

Although the bulk of the material classified as RVK/QRVK may have been produced by posteruptive resedimentation, it more than likely also contains deposits that could arguably be classified as syn-eruptively resedimented pyroclastic material. This is attributed to the fact that these deposits were formed in the chaotic environment within the crater underneath the eruption column, rather than proximal or distal to the crater. It is therefore not surprising that these deposits are difficult to classify within a pure, unmodified volcanological frame of reference.

\section{CONCLUSIONS}

The Jwaneng kimberlite consists of three adjacent steep-sided pipes infilled with two contrasting textural types of kimberlite: pale-coloured country rock xenolith- and fines-rich resedimented volcaniclastic kimberlite and dark pyroclastic kimberlite containing lower abundances of xenoliths and fines. The South and Centre Lobes were infilled initially with a quartz-rich resedimented volcaniclastic kimberlite (QRVK), now preserved as a narrow discontinuous marginal remnant, and a subsequent quartz-free RVK, which dominates the central portion of each pipe. The North Lobe is different in that it was infilled with only a quartz-free RVK and a later pyroclastic kimberlite.
Volcanological and sedimentological studies of the Jwaneng kimberlite indicate that it differs from other steep-sided southern African kimberlite pipes (e.g. Premier, Orapa), in terms of its extrusive volcaniclastic pipe infill, as well as its Permian age and contrasting country rock geology. The Jwaneng kimberlite therefore represents an exception to the majority of southern African kimberlites and thus must result from different emplacement mechanisms. This is in agreement with previous statements to this effect by Field and Scott Smith (1999). The morphology and internal geology of each of the Jwaneng pipes indicate dynamic and complex eruption histories involving phreatomagmatic activity, large-scale gravitational resedimentation and primary pyroclastic air-fall processes. The interplay between the various volcanic processes was influenced by a combination of the near-surface country rock geology and hydrogeological conditions, as well as the ascending magma.

\section{REFERENCES}

Clement, C.R., Skinner, E.M.S., 1985. A textural-genetic classification of kimberlites. Trans. Geol. Soc. S. Afr., 88, pp 403-409.

Clement, C.R. and Reid, A.M., 1989. The origin of kimberlite pipes: an interpretation based on a synthesis of geological features displayed by southern African occurrences. In: Ross J. et al. (eds), Kimberlites and Related Rocks, Vol. 1. Geol. Soc. Australia Spec. Publ., 14, pp $632-646$.

Field, M. and Scott Smith, B.H. 1998. Textural and genetic classification schemes for kimberlites: a new perspective. In: Extended Abstracts of the VIIth International Kimberlite Conference, Cape Town. pp $214-216$.

Field, M. and Scott Smith, B.H. 1999. Contrasting geology and near-surface emplacement of kimberlite pipes in Southern Africa and Canada. In: Proceedings of the VIIth International Kimberlite Conference, Cape Town. Vol. 1, pp $214-237$.

Machin, K. J. 2001. Processes and products in kimberlitic crater facies of the South Lobe, Jwaneng Mine, Botswana. Unpubl. M.Sc. thesis, Rhodes University, South Africa.

Contact: K.J. Webb

kimberley.webb@ca.debeersgroup.com 